Wien Klin Wochenschr (2018) 130:689-691

https://doi.org/10.1007/s00508-018-1422-0

CrossMark

\section{To the next decade}

\author{
Gerold Stanek
}

(C) Springer-Verlag GmbH Austria, part of Springer Nature 2018

With this issue the Wiener klinische Wochenschrift is completing its 130th year. The Journal has been continuously published since 1888 with the exception of the year 1945. Its presence in different historical epochs has been delineated in review articles by Otto Kraupp [1] and Helmut Wyklicky [2] on the occasion of 100 years of the Wiener klinische Wochenschrift and in 1998 by Wilfred Druml, who reflected on the fate of the Wiener klinische Wochenschrift in the years 1938-1945 and the 50th anniversary of its reappearance in 1946 [3].

In this commemoration year, the Gedenkjahr 2018, Austria is remembering the end of the First World War, the 100th anniversary of the founding of the Austrian Republic, the Anschluss of 1938 and the consequences of the Nazi regime. The Wiener klinische Wochenschrift is contributing to this with two supplements concerning medical ethics after the Nuremberg Code [4] and the aftermath on medicine and society [5].

In the very first issue of the Wiener klinische Wochenschrift in 1888, the editorial board announced the program expected to be realized with this journal (see Fig. 1). The basic aims of the original program still correspond well to our current goals-here are two sentences that have been selected and rendered in free translation:

In the pursuit of elevating domestic periodical journalism in the field of medicine to a higher scientific level and dignified standing, large numbers of colleagues have made commitments to

G. Stanek, M.D. $(\bowtie)$

Center for Pathophysiology, Infectiology and Immunology, Institute for Hygiene and Applied Immunology, Medical University of Vienna, Kinderspitalgasse 15, 1090 Vienna, Austria

gerold.stanek@meduniwien.ac.at

\section{Wiener klinische Wochenschrift} The Central European Journal of Medicine

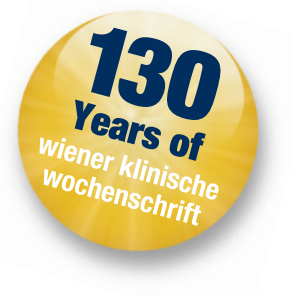

each other to foster and promote both their own work and that of their assistants and students.

As collaborators, we welcome all who would commit the results of significant scientific work to our Journal, not only from within our country but also from neighbouring countries and beyond.

We, the editors, are pleased that we have managed to further structure the journal in recent years, which has resulted in increased bibliometric perception. We cordially invite all our colleagues to submit the results of their scientific work to the Wiener klinische Wochenschrift. Many Austrian medical institutions are offered free open-access publication by Springer Medicine, making it easy for readers worldwide to access the publications. We further wish to include more and more readers who not only download the articles but acknowledge them by citation in their own work.

The Editors of the Wiener klinische Wochenschrift would like to thank all the authors who submitted their work during this WKW decade and in particular all the reviewers for their careful and in many cases most educational work, which benefits both the authors and the Journal.

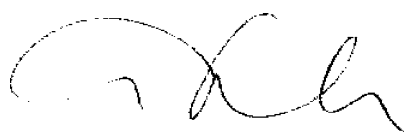

Gerold Stanek and all editors of the WKW

Conflict of interest Gerold Stanek declares that he has no competing interests. 


\section{Wiener klinische Wochenschrift}

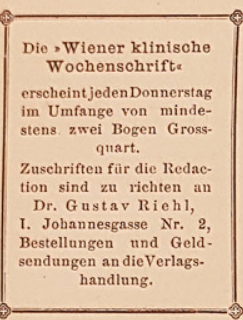

unter stïndiger Mitwirkung der Herren Professoren Drs.

E. Albert, Th. Billroth, C. Braun R. v. Fernwald, G. Braun, A. Breisky, S. Exner, E. Fleischl
v. Marxow, M. Gruber, E. R. v. Hofmann, Th. Meynert, S. Stricker, C. Toldt, A. Vogl,

herausgegeben von

Heinrich v. Bamberger, Ernst Fuchs, Hans Kundrat, Ernst Ludwig und Leopold Schrötter Ritter von Kristelli.

Organ der k. k. Gesellschaft der Aerzte in Wien.

Redigirt von Dr. Gustav Riehl.

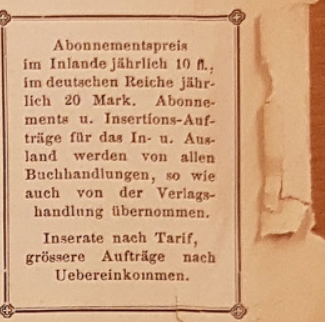

Verlag von Alfred Hölder, k. k. Hof- und Universitäts-Buchhändler, I. Rothenthurmstrasse I5.

\section{Jahrgang.}

Wien, 5. April 1888.

Nr. itete,

Inhalt: Programm. - Ueber die Ligatur der Schilddrüsenarterien behufs Einleitung der Atrophie von Kröpfen. Von Dr. Th. Billroth. - Ulriori Anwendbarkeit der Oertel'schen Heilmethode bei Klappenfehlern des Herzens. Von Prof. H. v. B amberger. - Angebliche Nothzucht mit nachfol J1sBlennorrhoe und hystero-epileptischen Anfällen. Fraglicher Geisteszustand. Von Prof. E. v. Hofmann in Wien. - Verhandlungen ärztlicher Ge schaften und Vereine: Physikalisch-medicinische Gesellschaft zu Würzburg. 3. und 17. März. - Referate: Neuere Heilmittel. Von P. Dr. J. Moeller in Innsbruck. - Bericht über Leistungen und Fortschritte auf dem Gebiete der Krankheiten des Kehlkopfes und der Luftröhre. Vom Docenten Dr. O. Chrari. - Amtliche Mittheilungen. Vergleich der Stadt Wien mit den Vororten und einigen Städten bezüglich des Verhaltens der Infections. krankheiten. - Militärärztliches. - Notizen. - Erledigte Stellen.

\section{Programm.}

Von dem Streben geleitet die heimische periodische Publicistik auf dem Gebiete der practischen Medicin aj Jer

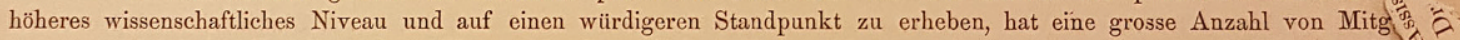
unserer medicinischen Facultät sich zur Herausgabe dieser Zeitschrift entschlossen und sich gegenseitig verpflichtet, sowohl ihre eigenen Arbeiten, als die ihrer Assistenten und Schüler dieselbe mit allen ihren Kräften zu fördern und zu unterstützen.

Sie geben sich der begründeten تrufriüng hin, dass dieses Unternehmen nicht nur dem wissenschaftlichen Streben einen neuen kräftigen Impuls verleihen, sondern auch unserem theueren Vaterlande und der altberühmten Wiener Schule zur Ehre gereichen werde.

Als Mitarbeiter sind Alle willkommen, welche die Resultate ernster wissenschaftlicher Arbeit unserem Blatte-anvertrauen wollen - nicht nur aus der engeren Heimat, sondern auch aus dem Auslande und vor allem aus dem stammverwandten, unserem Herzen so nahe stehenden deutschen Reiche.

Der Zweck des Blattes soll zunächst darin bestehen, dem practischen Arzte aus allen Zweigen der angewandter Medicin und ihrer theoretischen Nebenfächer das wichtigste Neue in conciser Form zur Kenntniss zu bringen, und andererseit: für kleinere Original-Arbeiten und interessante casuistische Mittheilungen eine passende Aufnahmsstätte zu eröffnen. Insbesonder soll das so ausserordentlich reiche casuistische Materiale der Wiener Kranken-Anstalten, namentlich der Kliniken in weit ausgedehnterem Maasse als bisher verwerthet und dem Leser zugänglich gemacht werden, so wie auch klinische Vorträge abe wichtige und seltenere Fälle, von den betreffenden Docenten selbst redigirt, darin Aufnahme finden werden.

Angelegenheiten, welche die Universität und den Unterricht, die Interessen des ärztlichen Standes und einzelner, dèmselben angehörigen Persönlichkeiten betreffen, sollen in rein objectiver, keinem Parteistandpunkte, und keinen egoistischen Beweggründen zugänglichen Weise und in einer der Facultat würdigen Form von berufener -und sachkundiger Seite besprochen werden.

Sowohl aus dem Inlande als dem Auslande hat bereits das unterzeichnete Redactions-Comité zahlreiche Aeusserungen der wärmsten Sympathie für das neue Unternehmen und Zusagen der Mitbetheiligung an demselben erhalten, so wie auch eine grosse Anzahl erprobter Fachmänner die Aufgabe übernommen hat, für dasselbe Referate und Besprechungen aller neuen Arbeiten aus dem Gebiete der practischen Medicin und ihrer Hilfswissenschaften zu liefern.

Der Tendenz des Blattes zustimmend, hat der erste ärztliche Verein Oesterreichs, die k. k. Gesellschaft der Aerzte in Wien, in ihrer Plenarversammluug vom 3. Februar 1888 mit grosser Stimmenmehrheit beschlossen, die •Wiener klinische Wochenschrifte als ihr Organ zu betrachten und vom April d. J. angefangen, das authentische Protokoll ihrer wissenschaftlichen Sitzungen in demselben zu veröffentlichen.

Die Zeitschrift wird somit als Organ der k. k. Gesellschaft der Aerzte fungiren.

Die, Wiener klinische Wochenschrift a wird ferner vom k. k. Ministerium des Innern, dem k. k. Ministerium für Cultus und Unterricht, der hohen niederösterreichischen Statthalterei, dem Sanitäts-Departement des k. k. Reichs-Kriegsministeriums und dem Stadtphysikate in Wien amtliche Mittheilungen publiciren.

Fest überzeugt, dass unserem redlichen und andauernden Streben auch der Erfolg nicht fehlen werde, empfehlen wir die Zeitschrift dem Wohlwollen aller ärztlichen Kreise.

Das Redactions-Comité:

\section{H. v. Bamberger, E. Fuchs, H. Kundrat, E. Ludwig, L. R. v. Schrötter}

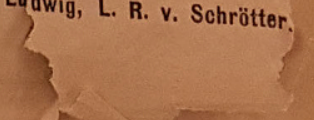

Fig. 1 Program of the very first issue (photo by Michael Reiter) 


\section{Translation of the program of the very first issue (see Fig. 1)}

\section{Program (Wien Klin Wochenschr Volume 1, Issue 1)}

In the pursuit of elevating domestic periodical journalism in the field of practical medicine to a higher scientific level and a dignified standing, a large number of members of our medical faculty have resolved upon publishing this Journal and have together undertaken, with all their might, to foster and promote both their own work and that of their assistants and students. They cherish well-founded hopes that this endeavour will not only confer a vigorous new impetus to scholarly aspirations but also redound to the honour of our beloved Fatherland and the long-famous Viennese School. As collaborators all are welcome who would commit the results of sober scientific work to our Journal-not only from within our homeland but also from abroad and especially the cognate German Empire so close to our hearts. The first purpose of the Journal shall be to concisely bring the most important novelties from all branches of applied medicine and its theoretical subsidiaries to the practitioner's knowledge. The second shall be to establish an appropriate placement for smaller original works and interesting casuistic communications. In particular, the so extraordinarily rich casuistic material emanating from the hospitals of Vienna, namely the clinics, is to be utilized far more prodigiously and rendered accessible to the reader as well as admitting clinical presentations on important and rare cases, personally redacted by the docents concerned.

Affairs pertaining to the University and instructions, the interests of the medical profession and of those individuals affiliated with the said profession shall be debated in a purely objective fashion, inaccessible to partisan standpoints and self-seeking incitements, in a form worthy of the faculty and from a competent and proficient side.

The undersigning Editorial Committee has already received expressions of the warmest sympathy, in large numbers and both domestic and foreign, for the new endeavour as well as pledges of participation in the said endeavour. A large number of tested specialists have assumed the assignment to deliver presentations and reviews of all recent work in the field of practical medicine and its ancillary disciplines.

In concordance with the Journal's tendency the principal medical association in Austria, the Imperial Royal (I. R.) Society of Physicians in Vienna, has adopted the resolution on the occasion of its plenary session from 3 February 1888, with a vast majority of votes, to acknowledge the Wiener klinische Wochenschrift as its official journal, while releasing the authentic protocol of its scientific sessions in the Journal commencing with April of that year.

The Journal shall hence serve as the official journal of the I. R. Society of Physicians. Moreover, the Wiener klinische Wochenschrift shall publish official notifications issued by the I.R. Ministry of the Interior, the I.R. Ministry of Education and Religious Affairs, the High Government of Lower Austria, the Medical Department of the I. R. Ministry of War and the Municipal Physician's Office in Vienna.

To the best of our belief that our righteous and persistent aspirations shall not be denied success, we commend the Journal to the benevolence of all medical circles.

The Editorial Committee:

H. von Bamberger, E. Fuchs, H. Kundrat, E. Ludwig, L. R. von Schrötter

translated by Mag Karl Thomanek

\section{References}

1. Kraupp O. 100 Jahre Wiener klinische Wochenschrift. Wien Klin Wochenschr. 1988;100:221-8.

2. Wyklicky H. Die "Wiener klinische Wochenschrift" von 1888-1970. Wien Klin Wochenschr. 1988;100:228-45.

3. Druml W. The Wiener klinische Wochenschrift from 1938 to 1945 ON the 50th anniversary of its reapparence in 1946. Wien Klin Wochenschr. 1998;110:202-5.
4. Czech H, Druml C, Weindling P. Medical ethics in the 70 years after the Nuremberg code, 1947 to the present. Wien Klin Wochenschr. 2018;130(Suppl3):159. https://doi.org/ 10.1007/s00508-018-1343-y.

5. Schütz W, Erker L, Rathkolb O, Sitte HH. Anschluss 1938: aftermath on medicine and society. Wien Klin Wochenschr. 2018;130(Suppl 5):279. https://doi.org/10.1007/s00508018-1366-4. 